\title{
The effect of large audit firm mergers on audit pricing in the $\mathrm{UK}^{1}$
}

by

\section{Kevin P. McMeeking}

School of Business and Economics, University of Exeter,

Streatham Court, Exeter EX4 4PU

Tel: +44 1392 263206,fax: +44 1392 263210,e-mail: k.p.mcmeeking@exeter.ac.uk

\section{Ken V. Peasnell}

Management School, Lancaster University, Lancaster LA1 4YX

Tel: +44 1524 593977,fax: +44 1524 594334, email: k.v.peasnell@lancaster.ac.uk

\section{Peter F. Pope}

Management School, Lancaster University, Lancaster LA1 4YX

Tel: +44 1524 593976,fax: +44 1524 594334, email: p.pope@lancaster.ac.uk

\section{This paper is forthcoming in Accounting and Business Research}

\footnotetext{
${ }^{1}$ McMeeking is at Exeter University. Peasnell and Pope are at Lancaster University. This research benefited from the generous financial support from the International Centre for Research in Accounting. Previous copies of the paper were presented at the 2005 British Accounting Association Auditing SIG conference and the 2005 EARNet conference. We are very grateful to Ashni Singh and Richard Patterson for research assistance and for the helpful comments of Peter Moizer, Ilias Basioudis, Vivien Beattie, David Citron, Terry Cooke, Paul Dunnmore, Aasmund Eilifsen, Jere Francis, David Gwilliam, Pelham Gore, Jonathan Hayward, Clive Lennox, Mark Tippett, Stuart Turley, Steven Young, the editor (Pauleen Weetman) and two anonymous reviewers. Any remaining errors are the sole responsibility of the authors. Address for correspondence: Kevin McMeeking, School of Business \& Economics, Streatham Court, Exeter University, Exeter, EX4 4PU, email:k.p.mcmeeking@ex.ac.uk, Tel: (0044)+1392 263206 (direct line), (0044) +1392 263201 (secretary), Fax: (0044) +1392 263210
} 


\title{
The effect of large audit firm mergers on audit pricing in the UK
}

\begin{abstract}
This paper examines the effects on UK audit market concentration and pricing of mergers between the large audit firms and the demise of Andersen. Based on data over the period 1985-2002, it appears that mergers contributed to a rise in concentration ratios to levels that suggest concern about the potential for monopoly pricing. The high concentration ratios have not improved the level of price competition in the UK audit market. Our pooled models suggest that concentration ratios are associated with higher audit fees. The evidence suggests that the effects of mergers between big firms on brand name fee premium and on price competition vary depending on the particular circumstances. The brand name premium is strongest for the largest quartile of companies prior to the mergers. After the Big Six mergers, the premium increases for average-sized companies but falls for the smallest and largest companies. Following the PricewaterhouseCoopers merger, the premium increases for below median-sized clients but decreases for above median sized clients. For the Deloitte-Andersen transaction, the premium falls for the smallest and largest companies but increases for those in the second quartile. Our results provide evidence that auditees are likely to pay higher fees if their auditor merges with a larger counterpart. We attribute merger-related fee hikes to product differentiation, rather than anticompetitive pricing.
\end{abstract}




\section{The effect of large audit firm mergers on audit pricing in the UK}

\section{Introduction}

A large number of audit firms have combined in the UK since the 1980s. Table 1 shows that the various mergers and the demise of Andersen have reduced the number of first-tier accounting firms (hereafter Big Firms) from eight in 1985 to four in 2002. Industrial economists use the structure-conduct-performance paradigm to urge regulators to be wary of reductions in the number of suppliers. Interesting research questions raised by this paradigm are how and to what extent have the structure of the audit market and the pricing policies of the major accounting firms been affected by the mergers and Andersen transaction? We examine audit pricing in the context of the industry restructuring that occurred during the 1980-2003 period as a result of mergers between large audit firms and the disappearance of Andersen (hereinafter referred to as the 'Andersen transaction').

-Insert Table 1 about here-

This study contributes to the literature by testing the effect of structural changes in the market for audit services on concentration and the pricing of the audits of UK listed companies. The UK provides an interesting empirical setting for a number of reasons. UK companies have long reported audit fee information in their annual financial statements (Companies Act 1967), making it possible to carry out a longitudinal study that is not yet possible in the $\mathrm{US}^{2}$. Furthermore, the London market is one of the world's largest, making it easier to test theories of audit pricing than in small markets like Hong Kong. We have exploited these institutional features to

\footnotetext{
${ }^{2}$ US firms have only been required to disclose the fees paid to auditors in statements filed on or after 5 February 2001 (Securities and Exchange Commission, 2000). Researchers using US data have therefore had to focus on measures like the number of audits, clients' turnover or clients' asset values as the measurement base because of the lack of available audit fee data (Moizer and Turley, 1989: 42).
} 
conduct a more comprehensive study over a longer time frame than in the prior literature.

We find that the largest increases in concentration ratios coincided with Big Firm mergers in 1989, 1990 and 1997. By 2002, concentration ratios reached levels that are consistent with a market structure of just over four equal sized firms, exceeding levels normally associated with a tight oligopoly. These structural changes appear to have had a variable effect on audit fees. There is some evidence to suggest that the high concentration ratios have reduced the level of price competition, an effect that may be attributed to product differentiation. The ability of large audit firms to charge a brand premium might be a function of willingness to pay. This might be expected to be stronger for larger clients, and this is what we observe in the 19851988 period before the mergers. However, the pattern is more complex in the later part of our sample period. Our findings indicate that the brand name premium increased for average-sized companies (i.e., those in the second and third size quartiles) after the Big Six mergers but fell for the smallest and the largest companies. Following the PricewaterhouseCoopers merger, the brand name premium increased (decreased) for clients whose size is below the median (above the median). The picture is even more complex following the Andersen transaction - the premium fell for the smallest and largest client quartiles but increased for those in the second quartile. We attribute these findings to the Big Firms engaging in a product differentiation strategy. Our findings using nominal prices indicate that the 1989 merger raised the audit fees of Arthur Young clients relative to the same clients previously audited by Ernst and Whinney ${ }^{3}$ and the 1990 merger increased the Coopers

\footnotetext{
${ }^{3}$ The UK combination between Arthur Young and Ernst and Whinney on 1 September 1989 was officially a merger but was seen by some writers as a takeover by Ernst and Whinney because several of the previously high-ranking Arthur Young partners left the following year. This anecdotal evidence
} 
and Lybrand fee premium over Deloitte ${ }^{4}$. The 1997 merger reduced the size of the nominal fee discount offered by Price Waterhouse relative to Coopers and Lybrand. Up to the end of our sample period the 2002 transaction had no material effect on the nominal audit fees of Deloitte and Andersen former clients. Using inflation adjusted audit fees, we find that Coopers and Lybrand and Ernst and Young clients paid higher real audit fees relative to clients of the benchmark firm (KPMG). On the other hand, Andersen clients paid lower real audit fees in the run up to being forced out of business. This audit firm transaction is significantly different from the others because the Enron debacle left a stigma not present in other mergers.

The remainder of this paper is organized as follows. The next section reviews the extant literature. Section three outlines the research design. The data collection procedures are explained in section four. The results are presented in section five and a summary is provided in section six.

\section{Prior Research}

Industrial economists argue that market structure is intrinsically linked to firm behaviour and financial performance (Scherer and Ross, 1990; Martin, 1994). Scholars urge regulators to be wary of the pricing effects of merger-induced increases in market concentration (Stigler, 1968: 30; Gist and Michaels, 1995: 233; Romeo,

suggests that Ernst and Whinney had a stronger brand name reputation than Arthur Young (supporting the evidence of the fee regressions).

${ }^{4}$ The Deloitte case provides an exclusive opportunity to examine the effects of brand name. In July 1989, the US partners of Deloitte Haskins \& Sells and those of Touche Ross suggested a merger. Deloitte in the UK and Haskins \& Sells in the US had very different attitudes to this proposal. The US Deloitte partners overwhelming voted to proceed with the merger whereas the UK Deloitte partners chose to merge with Coopers and Lybrand with the official fusion to Coopers and Lybrand Deloitte taking place on 29 April 1990. The potential for confusion caused by two firms signing off as Deloitte was eased on 1 June 1992 when Coopers and Lybrand Deloitte dropped the name Deloitte, becoming Coopers and Lybrand. Coopers allowed Touche Ross to acquire the name Deloitte in 1996 to form Deloitte and Touche (Moizer, 2005:4). 
1999: 62). ${ }^{5}$ There is considerable evidence that audit market concentration has increased over time in the UK (Briston and Kedslie, 1984; Moizer and Turley, 1989; Beattie and Fearnley, 1994; Pong, 1999) and in other countries (Zeff and Fossum, 1967; Rhode et al, 1974; Hermanson et al., 1987; Wolk et al., 2001). Beattie and Fearnley (1994: 308) contend that, 'auditor concentration in the UK market for listed audit services has now almost reached the limit of a tight oligopoly, which is a market structure characterised by few rivals, stable market shares and medium to high entry barriers'. Concentration levels increased further following the PricewaterhouseCoopers merger and the demise of Andersen. The Sarbanes-Oxley Act (2002), the recommendations of the Treasury Committee (2002) and the Coordinating Group on Audit and Accounting Issues (2003) indicate the extent of the concerns about the audit services market in both the US and UK (Beattie et al., 2003: 251).

The extant literature on the effect of mergers on the economy is mixed (Francis et al., 1999). Consumer welfare will increase if mergers reduce marginal costs, create efficiencies and enhance product differentiation but will decrease if mergers enable tacit collusion over prices or if unilateral anticompetitive effects arise from non-tacit price collusion (Sullivan, 2002: 381-384). Concerns about the welfare implications of the 1989/90 mergers (Wootton et al. 1994: 58-59) were quietened by the lack of opposition from the Monopolies and Mergers Commission and the Office of Fair Trading in the UK and the Department of Justice in the USA, and by evidence that auditors significantly cut fees to win audits in the 1980s (Simunic, 1980; Francis and Simon, 1987; Simon and Francis, 1988; Pong and Whittington, 1994; Gregory

\footnotetext{
${ }^{5}$ Moizer and Turley (1989: 41) define concentration as 'the extent to which a relatively small number of audit firms account for a significant proportion of the total audit work carried out.'
} 
and Collier, 1996). ${ }^{6}$ Although Pong (2004) documents a $17.5 \%$ reduction in inflationadjusted UK audit fees from 1991 to 1995 , there has been little recent work that has addressed this issue. This lack of evidence, and the structural changes resulting from the PricewaterhouseCoopers merger and the demise of Andersen, have rekindled concerns about the competitiveness of the audit market (Hermanson et al., 1987; Gist and Michaels, 1995; Pong, 1998; Willekens and Achmadi, 2003) and worries that that consumer choice will be further impaired if further mergers or takeovers occur (Oxera Consulting Limited, 2006).

It is difficult to test the welfare effects of mergers because audit firms have traditionally been organised as unlimited liability partnerships. This makes access to proprietary data on costs and profitability impossible. Researchers have tried to circumvent this problem by examining audit fees before and after a combination, but the results have been mixed. Tai and Kwong (1997) analysed audit fees using Hong Kong data between 1988 and 1991. They found that real audit fees increased significantly over this period. Ivancevich and Zardkoohi (2000) compared accounting fundamentals for four US audit firms involved in the 1989/90 mergers against competitor firms that were not involved in mergers. Following the mergers, the market share and audit fees of the merged firms fell relative to their non-merging rivals. Menon and Williams (2001) examined US audit fees for international accounting firm clients between 1980 and 1997. They document a significant positive effect on audit fees for three years after mergers (1991-1993), but this premium subsequently disappears. Iyer and Iyer (1996) compared the UK audit fees earned by

\footnotetext{
${ }^{6}$ Opinion surveys have yielded results consistent with this research. One survey by the City Research Group found that $81 \%$ of the financial executives surveyed by the City Research Group questioning the audit fee (Anonymous, December 1991: 11). Another survey showed that $61 \%$ of the accountant respondents thought that 'discounting audit fees was widespread' (Lea, 1991). The leaked Price Waterhouse tender that allegedly included a $£ 900,000$ discount was also the subject of press comment (Plender, 1991).
} 
Big Eight firms in 1987 with Big Six firms in 1991. Although concentration levels increased over the period, there was no evidence of any associated significant increase in audit fees. Firth and Lau (2004) examine the effect of accounting firm mergers on audit fees using a sample of Hong Kong companies. Their paper investigates the effect of a merger on any audit fee premium that existed before the combination. They find that the size of the premium earned by a brand name firm (Deloitte Touche and Tohmatsu) over a non-brand name firm (Kwan Wong Tan and Fong) fell from 55\% before the merger to $34 \%$ shortly after the merger. In contrast, there was no change in the audit fee premium earned by two brand name firms (Price Waterhouse and Coopers and Lybrand) after the merger. These results suggest that pre-merger premiums of the brand name auditor pass to the other auditor after a merger but do not transfer for re-branding amongst international firms.

\section{Research Design}

The present study contributes to this literature by testing the effects of the 1989/90 Big Six mergers, the 1997 merger between Price Waterhouse and Coopers and Lybrand and the 2002 Deloitte-Andersen transaction on audit pricing in the UK. We start our analysis by estimating concentration ratios to assess the potential for monopoly pricing in the audit market. Consistent with prior work, we define audit activity based on the number of audit clients each audit firm has and the firm's audit fee revenue (Wootton et. al., 1994; Pong, 1998, 1999; Wolk et. al., 2001). We use the concentration ratio $(\mathrm{CR})$ and Herfindahl Index $(H)^{7}$ because these are widely used by

\footnotetext{
${ }^{7}$ The concentration ratio $(C R)$ measures the percentage of the total activity (e.g. number of clients or size of audit fees) that is accounted for by the largest firms as follows:

$$
C R_{n}=\sum_{i=1}^{n} S_{i}
$$
}


academics and regulators such as the US Department of Justice (Utton, 1970; Briston and Kedslie, 1984; Moizer and Turley, 1989; Beattie and Fearnley, 1994; Pong, 1999). $C R$ and $H$ are descriptive statistics that prima facie suggest whether one should be concerned about the potential for anti-competitive pricing in the audit market. A positive result leads us to investigate whether the UK audit market has become more monopolistic following the accounting firm mergers. Our analysis focuses on the mergers between international accounting firms because these combinations are fewer in number and are likely to have a larger impact on market structure and conduct than those taking place between smaller firms.

\subsection{Empirical Questions}

The central issue is the effect of the big firm mergers on audit pricing, which we sum up in the following question:

EQ1: What are the fee effects for clients of larger audit firms following mergers?

Mergers can improve consumer welfare by creating efficiencies or decrease consumer welfare by creating conditions conducive to monopoly pricing (Sullivan, 2002: 381384). Simunic (1980) argues that some segments of the market could be more competitive than others; this could have an impact on the effects of the mergers on audit pricing. We follow this line of thought by using the small client market as the

where $n$ is the number of large audit firms and $S_{i}$ is the size of audit firm $i$ as a percentage of the size of the market. This study uses the $N$-firm concentration ratio $\left(C R_{n}\right)$ to examine the dominance of the eight (1985-1989), six (1990-1996), five (1997-1999) and four (2000-2002) largest accounting firms over medium and small firms. Consistent with prior studies (Briston and Kedslie, 1984; Moizer and Turley, 1989; Beattie and Fearnley, 1994; Pong, 1999), we also use the four-firm concentration ratio (CR4) to express the percentage of the total activity that is accounted for by the leading four firms in the market. One limitation of these measures is that they pay little attention to the number and size of other firms in the market. The Herfindahl Index $(H)$ provides a more comprehensive measure (Utton, 1970: 35-51; Moizer and Turley, 1989: 44; Pong, 1999: 455):

$$
H=\sum_{i=1}^{M} S_{i}^{2}
$$

where, $M$ is the total number of (big and small) firms in the audit market and $S_{i}$ is the size of audit firm $i$ as a percentage of the size of the entire market. 
competitive benchmark and testing whether fees change around the time of the mergers. In other words, we test whether the mergers have enabled the brand name firms to pass on any cost savings associated with efficiencies to their clients in the form of a reduction in the assumed audit fee premium or allowed the Big Firms to use their power or reputation to increase the audit fee premium. This empirical question is tested by running a quality differentiation regression across sub-samples of clients partitioned by total assets in the periods surrounding the combinations: ${ }^{8}$

$$
L A F_{i}=\alpha_{1,0}+\beta_{1,1} \text { Controls }_{\mathrm{i}}+\beta_{1,2} \text { Brand }_{\mathrm{i}}+\varepsilon_{1, i},
$$

where $L A F$ is the natural logarithm of total audit fees ( $\left.£^{\prime} 000\right)$; Brand, is an indicator variable set equal to one if the auditor is a brand name firm and zero otherwise; Controls is a vector of control variables capturing audit fee determinants identified in the prior literature (e.g. Francis and Simon, 1987; Simon and Francis, 1988; Beatty, 1993; Anderson and Zeghal, 1994) as follows: $L T A=$ natural logarithm of total assets $\left(£^{\prime} \mathrm{M}\right) ; S u b=$ square root of the number of subsidiaries; Current $=$ ratio of current assets to current liabilities; Loss $=1$ if an operating loss was reported in any 1 of the prior 3 years, 0 otherwise; Quick = ratio of current assets less stock to current liabilities; $D T A=$ ratio of long-term debt to total assets; $R O I=$ ratio of earnings before interest and tax to total assets; Foreign = proportion of subsidiaries that are foreign operations; $Y E=1$ if the accounting year end is between December and March inclusive, 0 otherwise; and $\varepsilon_{1, i}$ is the regression residual. The control variables are designed to capture effort-related variation in audit fees $(L T A)$, litigation risk (DTA, ROI, Current and Quick) and complexity (Sub, Foreign).

The second issue we address concerns the effects of a merger on audit fees charged by specific audit firms around the time of the merger. There is a considerable

\footnotetext{
${ }^{8}$ The first subscript, 1 , in equation (1) signifies that the regression is based on equation (1), the second subscript, $i$, refers to firm-year.
} 
body of theory and evidence suggesting that the large accounting firms have differentiated themselves from smaller competitors on the basis of perceptions of quality and that they are able to attract premium fees for their investment in a brand name reputation (e.g. Francis and Simon, 1987; Simon and Francis, 1988; Beatty, 1993; McMeeking et al, 2006). A possible motive for smaller accounting firms to merge with larger ones is that it is expected that the clients of the smaller partner will be willing to pay more because of perceptions that the quality of the service provided will have increased as a result of the merger. This is most likely to take place when the disparity in size is marked. However, an interesting question is whether it also arises when both merger parties are large. In such circumstances, fees may rise due to market forces or product differentiation or fall due to economies of scale and/or scope (Francis, et. al., 1999). This leads us to our second research question:

EQ2: What are the fee effects for clients of audit firms merging with larger audit firms?

We test EQ2 in two ways. First, we run panel audit fee regressions for the subsample of companies whose auditors were involved in mergers. Following Firth and Lau (2004), we examine audit pricing over three time intervals: three years before the merger; the year of the merger, and three years subsequent to the merger. For the first three mergers, we also examine pricing over different event windows because the choice of appropriate window is not obvious, a priori. For the Deloitte-Andersen transaction, in 2002 we use only one post-transaction observation because of the lack of available data at the time of collection. Audit fee differences between the combining firms are captured using a series of dummy variables.

To capture audit fee variation for the Arthur Young and Ernst and Whinney merger in 1989, we restrict our sample to Arthur Young, Ernst and Whinney, and 
Ernst and Young clients. In other words, an auditee must have been both a postmerger client of Ernst and Young and also a pre-merger client of either Arthur Young or Ernst and Whinney ${ }^{9}$. Similarly, to model audit fee variation for the Coopers and Lybrand and Deloitte, Haskins and Sells 1990 merger, we restrict our sample to Coopers and Lybrand, Deloitte, Haskins and Sells and Coopers and Lybrand Deloitte clients. To be included in the sample, a company must have been both a pre-merger client of Deloitte, Haskins and Sells or Coopers and Lybrand and a post-merger client of Coopers and Lybrand Deloitte. To capture audit fee variation for the Price Waterhouse and Coopers and Lybrand 1997 merger, we restrict our sample to Price Waterhouse, Coopers and Lybrand and PricewaterhouseCoopers clients, with sample firms having to be both pre- and post-merger clients of these firms. Finally, for the Deloitte Touche and Andersen 2002 transaction, we restrict our sample to clients that before the transaction were audited by either Deloitte and Touche and Andersen and afterwards by the new Deloitte firm.

Based on the research design in Firth and Lau (2004), we use the following generic regression model to test how audit prices were affected by merger activity:

$$
\begin{aligned}
& \text { LAF }_{i}=\alpha_{2,0}+\beta_{2,1} \text { EWpre }_{i}+\beta_{2,2} \text { PostEY }_{i}+\beta_{2,3} \text { EYmerge }_{i}+\beta_{2,4} \text { CLpre }_{i}+\beta_{2,5} \text { PostCLD }_{i} \\
& +\beta_{2,6} \text { CLDmerge }_{i}+\beta_{2,7} \text { PWpre }_{i}+\beta_{2,8} \text { PostPWC }_{i}+\beta_{2,9} \text { PWCmerge }_{i}+\beta_{2,10} \text { DTpre }_{i} \\
& +\beta_{2,11} \text { Post }_{i}+\beta_{2,12} \text { Dmerge }_{i}+\beta_{2,13} \text { Controls }_{i}+\varepsilon_{2, i} .
\end{aligned}
$$

As before, $L A F$ is the natural logarithm of total audit fees ( $\left.£^{\prime} 000\right)$ and includes both pre- and post-merger observations; EWpre, PostEY, EYmerge, CLpre, PostCLD, CLDmerge, PWpre, PostPWC, PWCmerge, DTpre, PostD and Dmerge are

\footnotetext{
${ }^{9}$ We exclude clients of other auditors who switched to the combined Ernst and Young firm after the merger and pre-merger clients of either Arthur Young or Ernst and Whinney who defected to other audit firms. A problem with this design is that we might observe fee cutting by the non-defecting clients caused by their demanding a reward for staying loyal. This does not, however, affect what is of primary interest in our study, namely, the relative changes in the fees of clients of the combining audit firms. As we explain later, our models estimated across the full sample of audit clients circumvent the latter problem.
} 
dichotomous treatment variables. EWpre is set equal to 1 if the observation is prior to the merger and the auditor is Ernst and Whinney; if the auditor prior to the merger is Arthur Young or the observation is after the merger then EWpre is 0. PostEY is set equal to 1 for a post-merger observation and 0 otherwise. EYmerge is set equal to 1 for a post-merger observation where the client was originally audited by Ernst and Whinney and 0 otherwise. CLpre is set equal to 1 if the observation is prior to the merger and the auditor at that time is Coopers and Lybrand and 0 otherwise. PostCLD is set equal to 1 for a post-merger observation and 0 otherwise. CLDmerge is set equal to 1 if the observation is after the merger and the original auditor was Coopers and Lybrand and zero otherwise. PWpre is set equal to 1 if the observation is prior to the merger and the auditor at that time is Price Waterhouse and 0 otherwise. Post $P W C$ is set equal to 1 for a post-merger observation and 0 otherwise. PWCmerge is set equal to 1 if the observation is after the merger and the original auditor was Price Waterhouse and zero otherwise. DTpre is set equal to 1 if the observation is prior to the transaction and the auditor at that time is Deloitte Touche and 0 otherwise. PostD is set equal to 1 for a post-takeover observation and 0 otherwise. Finally, Dmerge is set equal to 1 if the observation is after the transaction and the original auditor was Deloitte Touche and zero otherwise. The first subscript, 2, signifies that the regression is based on equation (2), the second subscript, $i$, refers to firm-year, $\varepsilon_{2, i}$ is the regression residual and Controls is the vector of the same control variables as specified for model 1 .

The logic underlying this research design is as follows. A positive $\beta_{2,1}$ coefficient captures any premium that Ernst and Whinney earned over Arthur Young prior to the merger. A positive $\beta_{2,2}$ coefficient indicates the increase in fees experienced by Arthur Young clients following the merger and $\beta_{2,2}+\beta_{2,3}$ is the 
corresponding increase for Ernst and Whinney clients. Thus a positive $\beta_{2,3}$ coefficient captures the additional post-merger premium paid by clients originally audited by Ernst and Whinney. Similarly, a positive $\beta_{2,4}$ coefficient captures any premium that Coopers and Lybrand earned prior to the merger, a positive $\beta_{2,5}$ coefficient estimates the post-merger premium paid by continuing Deloitte, Haskins and Sells clients and a positive $\beta_{2,6}$ coefficient measures any incremental post-merger premium of the Coopers and Lybrand clients. $\beta_{2,7}$ captures any premium that Price Waterhouse earned prior to the merger, $\beta_{2,8}$ the post-merger premium paid by continuing Coopers and Lybrand clients and $\beta_{2,9}$ any incremental post-merger premium of the Price Waterhouse clients. $\beta_{2,10}$ captures any premium that Deloitte Touche earned prior to the transaction, $\beta_{2,11}$ the post-transaction premium paid by continuing Andersen clients and $\beta_{2,12}$ any incremental post-transaction premium of the Deloitte Touche clients.

One limitation of the Firth and Lau (2004) methodology is that mergerinduced audit fee changes cannot be distinguished from fee variations across the entire audit market. We circumvent this problem by testing audit pricing for the clients of the firms involved in the four mergers and those that were excluded from merger activity. We do this by running a pooled model that contains the previous control variables, a non-brand name firm dummy and dichotomous variables indicating whether the observations relate to a firm that was involved in the mergers. The advantages of this design is that it controls for omitted factors that might confound the results and allows one to see how any merger related premium varies vis-à-vis the firm that was not involved in merger activity with one of its international counterparts (KPMG). One problem with running a pooled estimation across the extended (1985 to 2002) time frame is that audit fees may increase significantly due 
to the effects of general price inflation. Following Pong (2004), we account for inflationary driven audit fee changes using measures of the retail price index to adjust the nominal audit fees into real audit fees based on the month of the company's financial year-end. Differences in real audit fees are captured using the following model:

$$
\begin{aligned}
& \text { LRAF }_{i}=\alpha_{3,0}+\beta_{3,1} \text { EWpre }_{i}+\beta_{3,2} \text { AYpre }_{i}+\beta_{3,3} \text { EYpost }_{i}+\beta_{3,4} \text { CLpre }_{i}+\beta_{3,5} \text { DHSpre }_{i} \\
& +\beta_{3,6} \text { CLpost }_{i}+\beta_{3,7} \text { PWpre }+\beta_{3,8} \text { Cpre }_{i}+\beta_{3,9} \text { PWCpost }_{i}+\beta_{3,10} \text { Dpre }_{i}+\beta_{3,11} \text { Apre }_{i} \\
& +\beta_{3,12} \text { Dpost }_{i}+\beta_{3,13} \text { NBF }+\beta_{3,14} \text { Controls }_{i}+\varepsilon_{3, i} .
\end{aligned}
$$

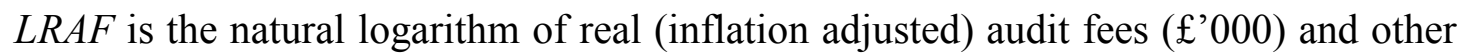
variables are as defined before (see Table 2).

-Insert Table 2 about here-

\section{Data Collection}

The data were taken from a population of 1,596 UK companies listed on both the London Stock Exchange and the Standard and Poor's Global Vantage database. Our final sample consists of a wide range of clients that reported data on the Global Vantage, Thomson Analytics Worldscope Datastream International, Extel Company Research databases and the International Stock Exchange Yearbook. Data on total assets, debt, earnings before interest and tax, financial year end, quick ratio, current ratio, operating profit and industry listing code data were collected for the period 1985-2002 from the Global Vantage and Thomson Analytics Worldscope databases. Audit data were collated from the Datastream International, Extel Company Research and Thomson Analytics Worldscope databases. Subsidiary and auditor identity data were hand collected from hard copies of the International Stock Exchange Yearbook and published annual reports. We eliminated financial firms from the analysis because of lack of comparability with non-financial firms' financial statements and because 
the cost structure of audits in financial firms differs significantly from those of industrials. Extreme observations in the top and bottom percentiles of total assets, total debt, operating profit, pre-tax profits, earnings before interest and tax and audit fees were eliminated from the sample. ${ }^{10}$ The final sample comprises 7,255 firm-year observations covering the period 1985-2002.

Consistent with other studies, the models include logarithmic or square root transformations of the value of audit fees, total assets and subsidiaries variables, as appropriate. This mitigates the possibility that large auditees will dominate the results. Table 3 presents descriptive statistics and shows how these transformation procedures reduced the extent of skewness in the distribution of the assets, debt and earnings variables.

- Insert Table 3 about here-

Untabulated Pearson correlation coefficients are mostly insignificant. In relation to the explanatory variables, the correlation coefficients between Current and Quick (0.69) and between LTA and Sub (0.59) are the only ones of any magnitude. However, untabulated variance inflation factors were all lower than the conventional cut-off point of 10 , suggesting that it is unlikely that multicollinearity materially affects our findings.

\section{Results}

\subsection{Descriptive Statistics}

Market share estimates based on the number of audit clients $\left(C R_{n}, C R 4\right.$ and $\left.H\right)$ from 1985 to 2002 are reported in Table 4. Between 1985 and 2002, $\mathrm{CR}_{\mathrm{n}}$ increased from $65 \%$ to $83 \%$, CR4 from $45 \%$ to $80 \%$ and $\mathrm{H}$ from $13 \%$ to $22 \%$ based on the number of

\footnotetext{
${ }^{10}$ However, the key results are not materially different regardless of whether the extreme observations are Winsorised or included in the sample.
} 
audit clients. Using the audit fee as a measurement basis, $\mathrm{CR}_{\mathrm{n}}$ increased from $77 \%$ to $95 \%$, CR4 from $59 \%$ to $88 \%$ and $\mathrm{H}$ from $13 \%$ to $23 \%$ over the same period. .

As a basis of comparison, the Herfindahl findings for 2002 are equivalent to a market of just over four firms of equal size and are even larger than the levels identified in the prior UK literature (9.6\%, Moizer and Turley, 1989:45; 16.97\%, Pong, 1999:472) as signifying a tight oligopolistic market structure ${ }^{11}$. Concentration ratios increased rapidly around the time of the Big Firm mergers and reached levels in 2002 that suggest that that the potential for price collusion is high. Unreported auditor market shares across four quartiles defined by client size indicate that concentration is an increasing function of client size. The high and increasing levels of concentration based on numbers of audit clients and on fee revenues suggest that that the potential for price collusion is particularly high in the largest client segment. The issue we turn to next is the impact this industry consolidation had on the relative rankings of audit firms.

- Insert Table 4 about here -

Rankings of the audit firms based on estimated market share of audit fees are reported in Table 5. The leading four firms in 1985 were Peat Marwick, Deloitte Haskins and Sells, Price Waterhouse and Touche Ross. Consistent with Moizer (2005), we find that Deloitte Haskins and Sells and Ernst and Whinney had larger market shares than Coopers and Lybrand and Arthur Young respectively in 1987 and the Big 6 mergers increased the market share of the merging firms to produce a new top four of KPMG, Coopers and Lybrand, Price Waterhouse and Ernst and Young. A

\footnotetext{
${ }^{11}$ We use the Parker (1991) methodology to compare the observed concentration ratios with their corresponding critical concentration ratios. Consistent with Willekens and Achmadi (2003:441), we compute the $5 \%$ critical levels to determine whether the market is significantly concentrated. We find that statistically significant concentration ratios are observed for $C R_{n}$ in 1988 and from 1992-1998 and for CR4 in 1985, 1986, 1988 and 1999-2000.
} 
substantial increase in market share of PricewaterhouseCoopers following the 1997 merger helped that firm to become the leading audit firm. The Andersen transaction resulted in a revised top four comprising PricewaterhouseCoopers, KPMG, Deloitte and Ernst and Young.

- Insert Table 5 about here -

\subsection{Monopolistic or Competitive Pricing}

We now turn our attention to the effect industry restructuring had on the pricing of audit services. The mean parameter estimates and $t$-statistics taken from the crosssection regressions are documented in the following tables for the areas of interest. The $t$-statistics are estimated using the White (1980) procedure because there is some evidence of heteroskedasticity. We show in bold type the coefficients that are significant at the $5 \%$ level or better. In all of the regressions, the models are significant at the $\mathrm{p}<0.01$ level, exhibit strong explanatory power $\left(R^{2}\right.$ generally around $70 \%$ ), and the control variables possess the anticipated signs and are significant at the $\mathrm{p}<0.05$ level (except Loss and ROI, which are sometimes insignificant).

Since concentration levels appear to have reached record levels by the end of the sample period, we investigate whether the mergers resulted in the Big Firms charging higher audit fees than their smaller counterparts and if so whether this is due to product differentiation or monopolistic pricing. Evidence that the audit firms were charging premium fees in a saturated market segment would be of interest to regulators, because this might be a sign of anticompetitive pricing policies. We first address this possibility by running model 1 across sub-samples partitioned across the quartile values of the size of the client for the years of the Big Firm mergers and each of the sub-periods where there were 8, 6, 5 and 4 dominant accounting firms. The results of these estimations are presented in Table 6. 
- Insert Table 6 about here -

The brand name premium is statistically significant in $1985-1988$ for most partitions and bigger for the two largest audit client quartiles, consistent with larger clients being willing to pay more for auditor reputation in this period. This pattern breaks down following the mergers in subsequent periods. The brand name premium is statistically significant for clients in the smallest quartile (the competitive benchmark) in 1985-1989 (17.4\%) 1991-1996 (8.8\%) and 1998-2001 (29.7\%). The brand name premium is insignificant for clients in the smallest quartile in 1989-1990 and 1997 and is significant and negative in 2002 (consistent with a highly competitive market). Similarly, for companies in the second largest quartile, significant brand name returns are observed in 1985-1988 (11.5\%), 1989-1990 (23.0\%), 1991-1996 (22.2\%), 1998-2001 (39.8\%) and $2002(87.8 \%)$. Significant brand name returns are observed for the subsample of companies in the third largest quartile in 1985-1988 (20.8\%) and 1991-1996 (25.8\%). For the largest quartile of companies, the brand name premium is statistically significant for 1985-1988 (37.1\%) and 1991-1996 (32.6\%). The statistically significant negative coefficients on Brand indicate that the audit fees paid to the Big Firms by the largest quartile of clients were significantly lower than those paid to their smaller counterparts in 1998-2001 (37.3\%) and 2002 $(53.6 \%)$.

If audit firms were engaging in anticompetitive pricing strategies, we would expect to see the strongest growth in brand name premia following mergers amongst client groups most willing to pay for reputation. Our mixed results in relation to client size suggest that willingness to pay a brand premium is not an increasing function of client size. Our findings indicate that subsequent to the Big Six mergers, the brand name premium increases for mid-sized clients (i.e., those in the second and third size 
quartiles) but falls in the quartiles containing the smallest (competitive benchmark) and largest companies. The brand name premium also increases for clients of below median size and falls for above-average sized clients following the PricewaterhouseCoopers merger. The picture is even more complex following the Deloitte-Andersen transaction, where the premium falls for the smallest and largest client quartiles but increases for those in the second quartile. Following the combinations, the brand name premium increases for companies in the second quartile but is volatile for all other quartiles. This pattern of results appears to be more consistent with the explanation that audit firms engage in product differentiation rather than anti-competitive pricing strategies. In other words, price increases occurred only where the mergers enabled the Big Firms to create new products or services that were more appealing to particular segments of the audit market. Our results suggest that such market segmentation is only loosely related to the size of the client.

\subsection{The Effect of Mergers on Audit Fees}

The results obtained by estimating equation (2) for the restricted sample of audit clients of firms involved in mergers three years before, the year of and three years ${ }^{12}$ subsequent to the combinations are documented in Table 7. These regressions are all significant at $\mathrm{p}<0.01$, have strong explanatory power $\left(R^{2}\right.$ of $\left.81 \%-85 \%\right)$ and the control variables exhibit the expected signs. The results reported in the third column of Table 7 are estimated using the sub-sample of 350 client-year observations relating to audits conducted by either Arthur Young or Ernst and Whinney before the merger, and by the new Ernst and Young firm after the merger. The coefficient of 0.148 on PostEY is

\footnotetext{
${ }^{12}$ One year for the Deloitte combination, due to a lack of data.
} 
positive and significant $(\mathrm{p}<0.05)$, consistent with Arthur Young clients paying a fee increase of the order of $16 \%$ after the merger. EYmerge is negative but insignificant, suggesting little or no change for in the audit fees of former Ernst and Whinney clients after the merger. EWpre is positive but not statistically significant, suggesting no systematic difference in audit fees paid by Ernst and Whinney clients from those paid by the clients of Arthur Young prior to the merger. These findings suggest that the merger eliminated the audit fee premium of Ernst and Whinney over Arthur Young. The results are consistent with Baskerville and Hay's (2006) argument that the combination was effectively a take-over by the larger firm, (Ernst and Whinney in the UK), and with the proposition that the merger improved the reputation of Arthur Young based on the rankings reported in Table 5 and in Moizer (2005).

The results reported in the fourth column of Table 7 are estimated using the sub-sample of 532 client-year observations relating to audits conducted by Coopers and Lybrand or Deloitte, Haskins and Sells before the merger, and by the new Coopers and Lybrand Deloitte firm after the merger. The coefficient on CLpre is not statistically significant, a finding consistent with Cooper and Lybrand clients and Deloitte, Haskins and Sells clients paying similar fees before the merger. The coefficient on PostCLD is also not statistically significant, implying that the clients of Deloitte, Haskins and Sells did not suffer a fee increase after the merger. However, the coefficient for CLDmerge is positive and significant $(\mathrm{p}<0.01)$ and converts to a $14 \%$ post-merger premium paid by Cooper and Lybrand clients. We interpret this as evidence that the brand name reputation of Coopers and Lybrand increased after the merger. This interpretation is consistent with the Table 5 and the Moizer (2005) rankings of Deloitte, Haskins and Sells and Coopers and Lybrand.

The results documented in the fifth column of Table 7 are estimated using the 
sub-sample of 978 client-year observations relating to audits conducted by Price Waterhouse or Coopers and Lybrand before the merger and by the new PricewaterhouseCoopers firm after the merger. PWpre is negative and significant at $\mathrm{p}<0.05$, suggesting that Price Waterhouse clients paid less for audit services than clients of Coopers and Lybrand before the merger. The coefficient of -0.078 corresponds to a $7.8 \%$ discount. The coefficient on PostPWC is not significant, indicating that Coopers and Lybrand clients did not suffer a post-merger fee increase. PWCmerge is not statistically significant, consistent with Price Waterhouse clients not paying more than did Coopers and Lybrand clients after the merger. These results suggest that the merger eliminated the significant discount offered to Price Waterhouse clients relative to Coopers and Lybrand clients. Consistent with the rankings documented in Moizer (2005) and Table 5, these findings suggest that the reputation of Price Waterhouse increased relative to Coopers and Lybrand when Price Waterhouse merged with the larger firm.

The results presented in the final column of Table 7 are estimated using a subsample of 117 client-year observations relating to audits conducted by Deloitte and Touche or Andersen before the transaction and by the new Deloitte firm after the transaction. For this combination, we modelled audit fees one year preceding and one year after the transaction because of the lack of availability of more recent data at the time of collection. Dmerge, DTpre and PostD are not significantly different from zero. Subject to the aforementioned caveat, this transaction does not seem to have had any material audit pricing effects. The two firms seem to have been on a similar footing prior to the transaction. The finding that the Dmerge coefficient is also insignificant suggests that Deloitte Touche's reputation did not suffer as a result of the Andersen transaction. 
-Insert Table 7 about here-

Finally, the results of our OLS merger estimation using inflation adjusted variables for the full sample of audit clients (model 3) are documented in Table 8. This regression is highly significant $(\mathrm{p}<0.01$ ), has strong explanatory power (adjusted R2 of $80 \%$ ) and the control variables exhibit the expected signs. The coefficient of 0.165 for the NBF variable is significant at $(\mathrm{p}<0.05)$, consistent with audit clients receiving a $15 \%$ discount relative to the benchmark firm (KPMG). The coefficient of 0.125 for the EYpost variable is statistically significant at $\mathrm{p}<0.05$, consistent with Ernst and Young clients accepting a 13\% increase in fees after the merger vis-à-vis the benchmark firm. The coefficient of 0.143 for the CLpost variable is statistically significant $(\mathrm{p}<0.01)$, implying that the clients of Coopers and Lybrand accepted a $15 \%$ fee increase after the merger. The coefficient of -0.108 for the Apre variable is significant at $\mathrm{p}<0.05$, suggesting that Andersen clients paid $10 \%$ less for audit services than the benchmark firm. These results are consistent with our earlier findings of product differentiation amongst the international accounting firms. The coefficients for the EWpre, AYpre, CLpre, DHSpre, PWpre, Cpre, PWCpost, Dpost and Dpre variables are all insignificant, suggesting that they paid similar audit fees to the benchmark firm.

-Insert Table 8 about here-

\subsection{Sensitivity Checks}

A series of sensitivity checks were performed to test the robustness of our findings. The results are not sensitive to the number of accounting firms used to measure concentration or the number of client size partitions created. Estimating model (1) across loss making and non-loss-making sub-samples provides a means of testing the 
sensitivity of the fee discounting findings to the financial performance of clients. We also sequentially excluded firms from model 1 to test whether one or a group of accounting firms might drive the results. Untabulated results indicate that the findings are not sensitive to client profitability or auditor size. We also varied the event window for model (3) using data for one, two, three and four years before and after the mergers, but results were not materially different. We tested the robustness of our findings to model specification by running the alternative estimations suggested by Firth and Lau (2004). Finally we ran two sets of regressions for the clients of merging firms before the mergers and for the same clients after the mergers. The general finding of these sensitivity checks is that our results are not materially affected by model specification.

\section{Summary and Conclusions}

This paper contributes to the literature by investigating the relationship between market concentration, accounting firm mergers and audit fee levels. We find that concentration ratios increased between 1985 and 2002 to levels that exceed those observed in the prior literature to form a tight oligopoly market structure. Increased levels of concentration seem to have reduced price competition and our client-sizepartitioned results suggest that this is due to product differentiation rather than anticompetitive pricing. The reduction in the number of top-tier audit firms has undoubtedly reduced auditee choice and increased the potential for conflicts of interest. The international firms have shown little signs of a willingness to de-merge their audit activities and many multinational companies do not see the mid-tier firms as a viable auditor because of their limited resources. We believe that regulators should carefully consider what they would do in the event that one of the Big Firms 
failed and a large corporation was forced to retain an audit firm because of the lack of available alternatives.

We also examine whether audit fee premiums or discounts are offered by international audit firms over their rivals and whether the pre-merger fee premiums of the stronger brand name auditor spread to the other auditor after a combination. Our results indicate that there are differences both within individual firms and across different firms in the pre- and post-merger levels of real and nominal audit fees. Looking first at nominal audit fees, we find that the Coopers and Lybrand Deloitte merger increased the audit fee premium of Coopers and Lybrand over the clients formerly audited by Deloitte. The Ernst and Young merger significantly increased the audit fees of former Arthur Young clients relative to those of Ernst and Whinney. The PricewaterhouseCoopers merger eliminated the discount offered by Price Waterhouse relative to Coopers and Lybrand clients. Finally, the Andersen transaction seems to have had no material effect to date. These results are consistent with the proposition that the brand name reputation of the smaller firms improved following the mergers with their larger counterparts. Finally, looking at real audit fees, we find that the Coopers and Lybrand Deloitte, Ernst and Young mergers and the Andersen transaction increased the audit fee premiums of Coopers and Lybrand and Ernst and Young and reduced the reputation problem associated with Andersen relative to clients audited by the benchmark firm that was not involved in merger activity (KPMG).

The study is subject to a number of limitations. In particular, caution should be exercised in assuming that these results can be generalized to apply to other countries and time periods because of differences in the structure of the markets and changes in the economic climate. Additionally, the paper might underestimate the extent of price- 
cutting because the auditor change variables are not able to distinguish more subtle market pressures. For example, auditor switch dummies will not identify cases where the incumbent auditor is reappointed in the tender process and any reductions will show as a fee cut by the incumbent auditor. Auditor switch dummies also cannot distinguish between efficiency gains, discounts from a normal fee and clients responding to excessively high fees by choosing to switch. Similarly, any fee reductions by the incumbent auditor resulting from pressure from the client, such as a threat to offer for tender, will not be identified. Furthermore, one is unable to generalize the results to all accounting firm mergers. We chose to focus on the pricing effects of mergers between the international accounting firms because they are likely to have a greater impact on concentration ratios and audit fees than mergers between small and medium sized firms due to their greater size and effect on market share. One downside with this is that the identity of the firm with the superior reputation is not obvious because the audit firms concerned are similar in size and level of expertise. Finally, due to the lack of available data, we are unable to investigate the effect of mergers on auditors' charge-out rates and costs. It is therefore impossible to ascertain whether the premium fees are distributed to partners, recognised in remunerating the employees of the firm or used to cover additional unforeseen costs. 


\section{References}

Anonymous (1991). 'Audits no longer value for money?' Accountancy, London, 108(1180): 11

Anderson, T. and Zeghal, D. (1994). 'The pricing of audit services: Further evidence from the Canadian market'. Accounting and Business Research, 24 (95):195-207.

Baskerville, R., and Hay, D. (2006). 'The effect of accounting firm mergers on the market for audit services: New Zealand evidence', Abacus, 42, (1): 87-104.

Beattie, V. A. and Fearnley, S. (1994). 'The changing structure of the market for audit services in the UK - a descriptive study'. British Accounting Review, 26(4):301-322. Beattie, V. A., Goodacre A. and Fearnley S. (2003). 'And then there were four: A study of UK audit market concentration - causes, consequences and the scope for market adjustment'. Journal of Financial Regulation and Compliance, 11 (3): 250265.

Beatty, R.P. (1993). 'The economic determinants of auditor compensation in the initial public offerings market'. Journal of Accounting Research, 31(2):294-302.

Briston, R., and Kedslie, M. (1984). 'Concentration in the profession - Danger signs?' Accountancy, 95(1095):11.

Coordinating Group on Audit and Accounting Issues (2003). Final Report to the Secretary of State for Trade and Industry and the Chancellor of the Exchequer, URN 03/567, Department of Trade and Industry, 29 January:1-103.

Firth, M. and Lau, T. (2004). 'Auditor pricing following mergers of accounting practices: Evidence from Hong Kong'. Accounting and Business Research, 34(3):201213.

Francis, J., D. Stokes and D. Anderson (1999). 'City Markets as a Unit of Analysis in Audit Research and the Re-examination of Big 6 Market Shares'. Abacus, 35(2):185- 
Francis, J. and Simon, D. (1987). 'A test of audit pricing in the small-company segment of the U.S. audit market'. Accounting Review', 62(January):145-157.

Gist, W, and Michaels, P. (1995). 'Auditor concentration and pricing of audit services: public policy and research implications'. Advances in Public Interest Accounting, 6:233-271.

Gregory, A., and Collier, P. (1996). 'Audit fees and auditor change; an investigation of the persistence of fee reduction by type of change'. Journal of Business Finance and Accounting, 23(1):13-28.

Hermanson, R.H, Dykes, L.M. and Turner, D.H. (1987). 'Enforced competition in the accounting profession - Does it make sense?' Accounting Horizons, 1(4): 13-19.

Ivancevich, S.H., and Zardkoohi, A. (2000). 'An explanatory analysis of the 1989 accounting firm megamergers'. Accounting Horizons, 14(4):389-401.

Iyer, V.M. and Iyer, G.S. (1996). 'Effect of Big 8 mergers on audit fees: Evidence from the United Kingdom'. Auditing: A Journal of Practice \& Theory, 15, (2):123132.

Lea, R. (1991). 'City accountants split on the issues of the day'. Accountancy Age, 27 June, 15.

Martin, S. (1994). 'Advanced industrial economics'. Blackwell Publishing Limited.

McMeeking, K. P., Pope, P.F., and Peasnell, K.V. (2006). 'The determinants of the UK Big Firm premium'. Accounting and Business Research, 36(3):207-231.

Menon, K. and Williams, D. (2001) 'Long term trends in audit fees'. Auditing: A Journal of Practice and Theory, 20(1):115-136.

Moizer, P and Turley, S. (1989). 'Changes in the UK market for audit services: 19721982'. Journal of Business Finance and Accounting, 16(1):41-53. 
Moizer, P. (2005). 'Mergers of UK accounting firms: the role of corporate identity'. University of Leeds University working paper.

Oxera Consulting Limited, (2006). Competition and choice in the UK audit market. A report for the Department of Trade and Industry, 12 April:1-101.

Parker, S. (1991). 'Significantly concentrated markets: Theory and evidence for the UK'. International Journal of Industrial Organization, 9(4):585-590.

Plender, J. (1991). 'Search for safe places to do business', Financial Times, 16 December:18.

Pong, C.K.M. (1998). ‘Hobson's choice?', Accountancy Age, 22 January:12-13.

Pong, C.K.M. (1999). 'Auditor concentration: a replication and extension for the UK audit market 1991-1995'. Journal of Business Finance and Accounting, 26(3-4):451475.

Pong, C.K.M. (2004). 'A descriptive analysis of audit price changes in the UK 19911995'. European Accounting Review, 13(1):161-178.

Pong, C.K.M. and Whittington, G. (1994). 'The determinants of audit fees: some empirical models'. Journal of Business Finance and Accounting, 21(8):1071-1095.

Rhode, J.G., Whitsell, G.M. and Kelsey, R.L. (1974). 'An analysis of client-industry concentrations for public accounting firms'. Accounting Review, 49(4):772-787.

Romeo, J. (1999). 'Looking at mergers the way federal regulators do'. Journal of Accountancy, December:59-64.

Scherer, F.M. and Ross, D.R. (1990). Industrial Market Structure and Economic Performance. Boston, Houghton Mifflin Co, 3rd Ed, 4.

Securities and Exchange Commission (2000). 'Revision of the Commission's auditor independence requirements'. (Release Nos 33-7919; 34-43602; File No S7-13-00), SEC, Washington, DC (also available at http://www.sec.gov/rules/final/33-7919.htm). 
Simon, D.T. and Francis, J.R. (1988). 'The effects of auditor change on audit fees: Tests of price cutting and price recovery'. Accounting Review, 63(2):255-269.

Simunic, D.A. (1980). 'The pricing of audit services: theory and evidence'. Journal of Accounting Research, 18(1):161-190.

Stigler, G.J. (1968). 'The organization of industry'. Homewood, IL, Richard D. Irwin. Sullivan, M.W. (2002). 'The effect of the Big Eight accounting firm mergers on the market for audit services'. Journal of Law and Economics, 45(2):375-399.

Tai, B., and Kwong, C. (1997). 'Auditor concentration and real audit fee changes among large audit firms in Hong Kong: A pre- and post- merger analysis'. Advances in International Accounting, 10:63-85.

Treasury Committee (2002). 'The Financial Regulation of Public Limited Companies'. HM Treasury, House of Commons, London.

Utton, M (1970). 'Industrial concentration', Penguin, Harmondsworth.

White, H., (1980). “A heteroskedasticity-consistent covariance matrix estimator and a direct test for heteroskedasticity", Econometrica, 48, 817-838.

Willekens, M. and Achmadi, C. (2003). 'Pricing and supplier concentration in the private client segment of the audit market: market power or competition?' International Journal of Accounting, 38(4):431-455.

Wolk, C.M., Michaelson, S.E. and Wootton, C.W. (2001). 'Auditor concentration and market shares in the US: 1988-1999 A descriptive note'. British Accounting Review, 33(2):157-174.

Wootton, C.W., Tonge, S.D. and Wolk, C.M. (1994). 'Pre and post big eight mergers: comparison of auditor concentration', Accounting Horizons, 8(3):58-74.

Zeff, S.A. and Fossum, R.L. (1967). 'An analysis of large audit clients', Accounting Review, 42(2):298-320. 
Table 1 History of mergers and takeovers involving first-tier accounting firms since 1984

\begin{tabular}{ccccc}
\hline Date & Country & $\begin{array}{c}\text { Attempted } \\
\text { merger }\end{array}$ & $\begin{array}{c}\text { Attempted } \\
\text { takeover }\end{array}$ & Failure/Success \\
\hline 1984 & US and UK & PW and DH & & Failure \\
1986 & US and UK & PM and KMG & & Success \\
1989 & US and UK & EW and AY & Success \\
1989 & US and UK & PW and AA & & Failure \\
1989 & US & DH and TR & Success \\
1989 & UK & DH and TR & & Failure \\
1990 & UK & DH and CL & & Success \\
1990 & UK & TR and SP & & Mainly success \\
1994 & US and UK & AA and BH & & Mixed \\
1997 & US and UK & CL and PW & & Success \\
1997 & US and UK & EY and KPMG & & Failure \\
2002 & UK & & D and A & Success \\
\hline
\end{tabular}

Audit partnerships are named as follows: $\mathrm{AA}=$ Arthur Andersen; $\mathrm{A}=$ Andersen; $\mathrm{AY}=$ Arthur Young; $\mathrm{BH}=$ Binder Hamlyn; $\mathrm{CL}=$ Coopers and Lybrand; $\mathrm{D}=$ Deloitte; $\mathrm{DH}=$ Deloitte Haskins and Sells; EW= Ernst and Whinney; EY= Ernst and Young; $\mathrm{KMG}=\mathrm{KMG}$ Thomson McLintock; $\mathrm{KPMG}=\mathrm{KPMG}$; $\mathrm{PM}=$ Peat Marwick; $\mathrm{PW}=$ Price Waterhouse; $\mathrm{SP}=$ Spicer and Pegler and $\mathrm{TR}=$ Touche Ross. 
Table 2 Definitions of the variables used in the real audit-pricing model (4)

\begin{tabular}{|c|c|}
\hline Variable & Definition \\
\hline EWpre & $\begin{array}{l}1 \text { if the observation is prior to the merger and Ernst and Whinney are the auditors } \\
\text { and Ernst and Young audit the client after the merger, } 0 \text { otherwise. }\end{array}$ \\
\hline AYpre & $\begin{array}{l}1 \text { if the observation is prior to the merger and Arthur Young are the auditors and } \\
\text { Ernst and Young audit the client after the merger, } 0 \text { otherwise. }\end{array}$ \\
\hline EYpost & $\begin{array}{l}1 \text { if the auditor prior to the merger is Ernst and Whinney, the observation is after } \\
\text { the merger and Ernst and Young audit the client, } 0 \text { otherwise. }\end{array}$ \\
\hline CLpre & $\begin{array}{l}1 \text { if the observation is prior to the merger and Coopers and Lybrand are the auditors } \\
\text { and Coopers and Lybrand Deloitte audit the client after the merger, } 0 \text { otherwise. }\end{array}$ \\
\hline DHSpre & $\begin{array}{l}1 \text { if the observation is prior to the merger and Deloitte, Haskins and Sells are the } \\
\text { auditors and Coopers and Lybrand Deloitte audit the client after the merger, } 0 \\
\text { otherwise. }\end{array}$ \\
\hline CLpost & $\begin{array}{l}1 \text { if the auditor prior to the merger is Coopers and Lybrand, the observation is after } \\
\text { the merger and Coopers and Lybrand Deloitte audit the client, } 0 \text { otherwise. }\end{array}$ \\
\hline PWpre & $\begin{array}{l}1 \text { if the observation is prior to the merger and Price Waterhouse are the auditors and } \\
\text { PricewaterhouseCoopers audit the client after the merger, } 0 \text { otherwise. }\end{array}$ \\
\hline Cpre & $\begin{array}{l}1 \text { if the observation is prior to the merger and Coopers and Lybrand are the auditors } \\
\text { and PricewaterhouseCoopers audit the client after the merger, } 0 \text { otherwise. }\end{array}$ \\
\hline PWCpost & $\begin{array}{l}1 \text { if the auditor prior to the merger is Price Waterhouse, the observation is after the } \\
\text { merger and PricewaterhouseCoopers audit the client, } 0 \text { otherwise. }\end{array}$ \\
\hline Dpre & $\begin{array}{l}1 \text { if the observation is prior to the transaction and Deloitte and Touche are the } \\
\text { auditors and Deloitte audit the client after the transaction, } 0 \text { otherwise. }\end{array}$ \\
\hline Apre & $\begin{array}{l}1 \text { if the observation is prior to the transaction and Andersen are the auditors and } \\
\text { Deloitte audit the client after the transaction, } 0 \text { otherwise. }\end{array}$ \\
\hline Dpost & $\begin{array}{l}1 \text { if the auditor prior to the transaction is Deloitte and Touche, the observation is } \\
\text { after the transaction and Deloitte audits the client, } 0 \text { otherwise. }\end{array}$ \\
\hline$N B F$ & 1 if a non brand-name firm audits the client, 0 otherwise. \\
\hline
\end{tabular}


Table 3 Descriptive Statistics for the sample of UK clients

\begin{tabular}{cccccccc}
\hline Variable & Mean & St. Dev. & Min & Q1 & Median & Q3 & Max \\
& & & & & & & \\
\hline Audit fee & 359.183 & 577.308 & 10 & 60 & 130 & 370 & 11400 \\
LAF & 5.031 & 1.264 & 2.267 & 4.094 & 4.868 & 5.914 & 9.341 \\
Total assets & 513.745 & 1465.451 & 0.355 & 40.214 & 120.365 & 387.547 & 22565 \\
LTA & 11.722 & 1.629 & 5.872 & 10.525 & 11.563 & 12.761 & 18.846 \\
Subsidiaries & 16.847 & 18.329 & 0 & 5 & 11 & 22 & 196 \\
Sub & 3.636 & 1.905 & 0 & 2.236 & 3.317 & 4.690 & 14 \\
Total debt & 152.751 & 401.362 & 0 & 3.672 & 15.146 & 64.400 & 18800 \\
Op. profit & 55.458 & 203.501 & -235.9 & 3.381 & 9.933 & 33.800 & 4252.000 \\
EBIT & 70.874 & 214.624 & -235.9 & 8.124 & 13.412 & 50.145 & 4120 \\
Revenue & 520.145 & 1267.987 & 0 & 54.21 & 142.875 & 403.124 & 15742 \\
LREV & 5.575 & 2.015 & -3.863 & 3.993 & 4.962 & 5.999 & 9.664 \\
Current & 1.573 & 0.815 & 0.015 & 1.150 & 1.431 & 1.827 & 8.987 \\
Quick & 0.939 & 0.666 & 0.012 & 0.626 & 0.856 & 1.114 & 8.864 \\
DTA & 0.100 & 0.135 & 0 & 0.013 & 0.072 & 0.147 & 3.612 \\
ROI & 0.098 & 0.155 & -1.345 & 0.065 & 0.111 & 0.152 & 0.692 \\
Foreign & 0.247 & 0.270 & 0 & 0 & 0.167 & 0.429 & 1 \\
Loss & 0.157 & 0.364 & 0 & 0 & 0 & 0 & 1 \\
YE & 0.691 & 0.472 & 0 & 0 & 1 & 1 & 1
\end{tabular}

Audit Fee $=$ Fee relating to the audit (£'000); LAF = natural logarithm of the audit fee (£'000); Total Assets $=$ Total assets $\left(£^{\prime} M\right)$; LTA = natural logarithm of total assets $\left(£^{\prime} M\right)$; Subsidiaries $=$ Number of domestic subsidiaries; Sub = square root of the number of subsidiaries; Total Debt = Total debt (£'M); Op. profit $=$ Operating profit $\left(£^{\prime} \mathrm{M}\right)$; EBIT $=$ Earnings before interest and tax $\left(£^{\prime} \mathrm{M}\right)$; Revenue = Total sales revenue ( $\left.£^{\prime} 000\right)$; LREV = natural logarithm of total sales revenue $\left(£^{\prime} 000\right)$; Current $=$ ratio of current assets to current liabilities; Quick = ratio of current assets less stock to current liabilities; DTA= ratio of long-term debt to total assets; ROI = ratio of earnings before interest and tax to total assets; Foreign $=$ proportion of subsidiaries that are foreign operations; Loss $=1$ if an operating loss was reported in any one of the prior 3 years, 0 otherwise; $\mathrm{YE}=1$ if the accounting year end is between December and March, 0 otherwise. 
Table 4 Auditor concentration ratios based on (a) the number

of audit clients and (b) the fee

CRs based on number of audit

CRs based on audit fee clients

\begin{tabular}{|c|c|c|c|c|c|c|c|c|}
\hline Year & $\begin{array}{l}\text { Number of } \\
\text { large firms }\end{array}$ & $\begin{array}{l}\text { Number of } \\
\text { observations }\end{array}$ & $\mathrm{CR}_{\mathrm{n}}$ & CR4 & $\mathrm{H}$ & $\mathrm{CR}_{\mathrm{n}}$ & CR4 & $\mathrm{H}$ \\
\hline 1985 & 8 & 225 & 0.65 & 0.45 & 0.13 & 0.77 & 0.59 & 0.13 \\
\hline 1986 & 8 & 288 & 0.65 & 0.45 & 0.12 & 0.77 & 0.57 & 0.11 \\
\hline 1987 & 8 & 358 & 0.66 & 0.44 & 0.11 & 0.81 & 0.59 & 0.13 \\
\hline 1988 & 8 & 430 & 0.69 & 0.48 & 0.12 & 0.81 & 0.59 & 0.12 \\
\hline 1989 & 7 & 446 & 0.71 & 0.49 & 0.12 & 0.81 & 0.57 & 0.12 \\
\hline 1990 & 6 & 473 & 0.72 & 0.55 & 0.13 & 0.81 & 0.71 & 0.14 \\
\hline 1991 & 6 & 496 & 0.73 & 0.56 & 0.13 & 0.82 & 0.72 & 0.16 \\
\hline 1992 & 6 & 488 & 0.76 & 0.55 & 0.13 & 0.88 & 0.76 & 0.17 \\
\hline 1993 & 6 & 488 & 0.77 & 0.56 & 0.14 & 0.89 & 0.79 & 0.18 \\
\hline 1994 & 6 & 461 & 0.79 & 0.58 & 0.14 & 0.89 & 0.78 & 0.18 \\
\hline 1995 & 6 & 485 & 0.80 & 0.61 & 0.14 & 0.90 & 0.80 & 0.18 \\
\hline 1996 & 6 & 442 & 0.81 & 0.61 & 0.16 & 0.94 & 0.86 & 0.22 \\
\hline 1997 & 5 & 421 & 0.84 & 0.61 & 0.16 & 0.93 & 0.86 & 0.23 \\
\hline 1998 & 5 & 387 & 0.84 & 0.69 & 0.15 & 0.96 & 0.82 & 0.21 \\
\hline 1999 & 5 & 361 & 0.84 & 0.79 & 0.21 & 0.95 & 0.88 & 0.28 \\
\hline 2000 & 5 & 343 & 0.84 & 0.78 & 0.22 & 0.95 & 0.87 & 0.26 \\
\hline 2001 & 5 & 354 & 0.83 & 0.76 & 0.20 & 0.94 & 0.85 & 0.24 \\
\hline 2002 & 4 & 309 & 0.83 & 0.80 & 0.22 & 0.95 & 0.88 & 0.23 \\
\hline
\end{tabular}

The table shows the number of large accounting firms and the mean values of the $\mathrm{n}$ firm concentration ratio, the four firm concentration ratio and Herfindahl index based on the number of audit clients and the fees relating to the audit of the accounting firms. The table documents concentration ratios from 1985 to 2002 (7,255 observations). The concentration ratio is defined as $C R_{n}=\sum_{i=1}^{n} S_{i}$, $C R 4=\sum_{i=1}^{4} S_{i}$ and the Herfindahl Index as $H=\sum_{i=1}^{M} S_{i}{ }^{2}$ where $\mathrm{n}$ is the number of large audit firms, $\mathrm{M}$ is the total number of firms in the market and $S_{i}$ is the size of audit firm $i$ as a percentage of the size of the market. 
Table 5 Audit firm rankings based on UK fees relating to the audit

\begin{tabular}{lllllllllllll}
\hline & AA & EW & AY & EY & CL & DHS & CLD & KPMG & PW & PWC & TR & D \\
\hline 1985 & 8 & 5 & 7 & & 6 & 2 & & 1 & 3 & & 4 & \\
1986 & 8 & 5 & 7 & & 6 & 3 & & 1 & 2 & & 4 & \\
1987 & 8 & 5 & 7 & & 6 & 3 & & 1 & 2 & & 4 & \\
1988 & 8 & 5 & 7 & & 6 & 3 & & 1 & 2 & & 4 & \\
1989 & 8 & 5 & 7 & & 6 & 3 & & 1 & 2 & & 4 & \\
1990 & 6 & & & 4 & & & 2 & 1 & 3 & & 5 & \\
1991 & 6 & & & 4 & & & 2 & 1 & 3 & & 5 & \\
1992 & 6 & & & 4 & & & 2 & 1 & 3 & & 5 & \\
1993 & 6 & & & 4 & & & 2 & 1 & 3 & & 5 & \\
1994 & 6 & & & 4 & & & 2 & 1 & 3 & & 5 & \\
1995 & 6 & & & 4 & & & 2 & 1 & 3 & & 5 & \\
1996 & 6 & & & 4 & & & 2 & 1 & 3 & & 5 & \\
1997 & 6 & & & 4 & & & 2 & 1 & 3 & & 5 & \\
1998 & 5 & & & 3 & & & & 2 & & 1 & 4 & \\
1999 & 5 & & & 3 & & & & 2 & & 1 & 4 & \\
2000 & 5 & & & 3 & & & & 2 & & 1 & 4 & \\
2001 & 5 & & & 3 & & & & 2 & & 1 & & 3 \\
2002 & & & & & & & & & & & & \\
\hline
\end{tabular}

The table shows the rankings of the large accounting firms based on the fees relating to the audit from 1985 to 2002. Firms are defined using their UK names in the year in question.

AA: Andersen (including its previous depiction of Arthur Andersen).

EW:Ernst and Whinney.

AY:Arthur Young.

EY:Ernst and Young (created by the merger of Arthur Young and Ernst and Whinney).

CL:Coopers and Lybrand.

DHS:Deloitte Haskins and Sells.

CLD:Coopers and Lybrand(created by the merger of Coopers and Lybrand with Deloitte Haskins and Sells).

KPMG: KPMG (including its previous depictions such as Peat Marwick).

PW:Price Waterhouse.

PWC:PricewaterhouseCoopers (created by the merger of Price Waterhouse with Coopers and Lybrand).

TR:Touche Ross.

D:Deloitte (created when the majority of Andersen's clients were subsumed into the firm Deloitte and Touche). 
Table 6 OLS regression models of log fees against brand name dummies for sub samples partitioned by client size in the pre and post merger periods surrounding the mergers

$L A F=\alpha_{1,0}+\beta_{1,1}$ Controls $+\beta_{1,2}$ Brand $+\varepsilon_{1, i}$. (1)

\begin{tabular}{|c|c|c|c|c|}
\hline Years & \multicolumn{4}{|c|}{$1985-1988$} \\
\hline State of market & 8 Big Firms & 8 Big Firms & 8 Big Firms & 8 Big Firms \\
\hline Sub-sample & Smallest & Second & Third & Largest \\
\hline LTA & LTA $<10.525$ & $10.524<\mathrm{LTA}<=11.563$ & $11.563<$ LTA $<=12.761$ & LTA $>12.761$ \\
\hline \multirow[t]{2}{*}{ Brand } & 0.160 & 0.109 & 0.189 & 0.315 \\
\hline & $(2.66)$ & $(1.73)$ & $(2.22)$ & (2.49) \\
\hline Premium & 0.174 & 0.115 & 0.208 & 0.371 \\
\hline $\mathrm{N}$ & 325 & 325 & 325 & 326 \\
\hline $\mathrm{F}$ & $25.53^{\mathrm{a}}$ & $31.84^{\mathrm{a}}$ & $20.66^{\mathrm{a}}$ & $14.01^{\mathrm{a}}$ \\
\hline $\operatorname{Adj} R^{2}$ & 0.70 & 0.71 & 0.70 & 0.69 \\
\hline Years & \multicolumn{4}{|c|}{$1989-1990$} \\
\hline State of market & Big 6 Mergers & Big 6 Mergers & Big 6 Mergers & Big 6 Mergers \\
\hline Sub-sample & Smallest & Second & Third & Largest \\
\hline LTA & LTA $<10.525$ & $10.524<\mathrm{LTA}<=11.563$ & $11.563<\mathrm{LTA}<=12.761$ & $\mathrm{LTA}>12.761$ \\
\hline \multirow[t]{2}{*}{ Brand } & 0.084 & 0.206 & 0.091 & 0.289 \\
\hline & $(1.21)$ & $(2.91)$ & $(0.80)$ & (1.77) \\
\hline Premium & 0.088 & 0.230 & 0.095 & 0.335 \\
\hline $\mathrm{N}$ & 229 & 230 & 230 & 230 \\
\hline $\mathrm{F}$ & $23.57^{\mathrm{a}}$ & $26.90^{\mathrm{a}}$ & $11.50^{\mathrm{a}}$ & $10.34^{\mathrm{a}}$ \\
\hline Adj $R^{2}$ & 0.75 & 0.82 & 0.58 & 0.61 \\
\hline Years & \multicolumn{4}{|c|}{$1991-1996$} \\
\hline State of market & 6 Big Firms & 6 Big Firms & 6 Big Firms & 6 Big Firms \\
\hline Sub-sample & Smallest & Second & Third & Largest \\
\hline LTA & $\mathrm{LTA}<10.525$ & $10.524<\mathrm{LTA}<=11.563$ & $11.563<$ LTA $<=12.761$ & $\mathrm{LTA}>12.761$ \\
\hline \multirow[t]{2}{*}{ Brand } & 0.084 & 0.206 & 0.229 & 0.282 \\
\hline & $(2.24)$ & $(4.39)$ & $(3.50)$ & $(2.69)$ \\
\hline Premium & 0.088 & 0.222 & 0.258 & 0.326 \\
\hline $\mathrm{N}$ & 715 & 715 & 715 & 715 \\
\hline $\mathrm{F}$ & $88.69^{\mathrm{a}}$ & $66.64^{\mathrm{a}}$ & $48.71^{\mathrm{a}}$ & $47.65^{\mathrm{a}}$ \\
\hline $\operatorname{Adj} R^{2}$ & 0.81 & 0.80 & 0.72 & 0.73 \\
\hline
\end{tabular}

a significant at the $1 \%$ level. The coefficients shown in bold are significant at the $5 \%$ level or lower. The dependent variable is the natural logarithm of audit fees.

The first row shows the parameter estimate and the second row the $t$ statistic (two-tailed) for each variable. The expected sign is positive.

Brand $=1$ if Big Firm auditor, 0 otherwise. 
Table 6 (cont) OLS regression models of log fees against brand name dummies for sub samples partitioned by client size

$L A F=\alpha_{1,0}+\beta_{1,1}$ Controls $+\beta_{1,2}$ Brand $+\varepsilon_{1, i}$. (1)

\begin{tabular}{|c|c|c|c|c|}
\hline Year & \multicolumn{4}{|c|}{1997} \\
\hline $\begin{array}{c}\text { State of market } \\
\text { Sub-sample }\end{array}$ & $\begin{array}{c}\text { PwC Merger } \\
\text { Smallest }\end{array}$ & $\begin{array}{c}\text { PwC Merger } \\
\text { Second }\end{array}$ & $\begin{array}{c}\text { PwC Merger } \\
\text { Third }\end{array}$ & $\begin{array}{c}\text { PwC Merger } \\
\text { Largest }\end{array}$ \\
\hline LTA & LTA $<10.525$ & $10.524<\mathrm{LTA}<=11.563$ & $11.563<\mathrm{LTA}<=12.76$ & $\mathrm{LTA}>12.761$ \\
\hline \multirow[t]{2}{*}{ Brand } & 0.115 & 0.002 & 0.175 & 0.097 \\
\hline & $(0.86)$ & $(0.01)$ & $(0.65)$ & $(0.27)$ \\
\hline Premium & 0.123 & 0.012 & 0.192 & 0.102 \\
\hline $\mathrm{N}$ & 105 & 105 & 106 & 105 \\
\hline $\mathrm{F}$ & $19.54^{\mathrm{a}}$ & $12.57^{\mathrm{a}}$ & $28.71^{\mathrm{a}}$ & $13.51^{\mathrm{a}}$ \\
\hline $\operatorname{Adj} R^{2}$ & 0.88 & 0.70 & 0.72 & 0.84 \\
\hline Years & \multicolumn{4}{|c|}{$1998-2001$} \\
\hline State of market & 5 Big Firms & 5 Big Firms & 5 Big Firms & 5 Big Firms \\
\hline Sub-sample & Smallest & Second & Third & Largest \\
\hline LTA & LTA $<10.525$ & $10.524<\mathrm{LTA}<=11.563$ & $11.563<\mathrm{LTA}<=12.761$ & LTA $>12.761$ \\
\hline \multirow[t]{2}{*}{ Brand } & 0.260 & 0.334 & 0.053 & -0.467 \\
\hline & $(3.14)$ & (3.63) & $(0.49)$ & $(2.60)$ \\
\hline Premium & 0.297 & 0.398 & 0.055 & -0.373 \\
\hline $\mathrm{N}$ & 361 & 361 & 361 & 362 \\
\hline $\mathrm{F}$ & $13.99^{\mathrm{a}}$ & $17.14^{\mathrm{a}}$ & $20.01^{\mathrm{a}}$ & $56.12^{\mathrm{a}}$ \\
\hline $\operatorname{Adj} R^{2}$ & 0.67 & 0.74 & 0.76 & 0.86 \\
\hline Years & \multicolumn{4}{|c|}{2002} \\
\hline State of market & & & & \\
\hline & $\begin{array}{l}\text { Andersen } \\
\text { transaction }\end{array}$ & $\begin{array}{l}\text { Andersen } \\
\text { transaction }\end{array}$ & $\begin{array}{l}\text { Andersen } \\
\text { transaction }\end{array}$ & $\begin{array}{l}\text { Andersen } \\
\text { transaction }\end{array}$ \\
\hline Sub-sample & Smallest & Second & Third & Largest \\
\hline LTA & LTA $<10.525$ & $10.524<\mathrm{LTA}<=11.563$ & $11.563<\mathrm{LTA}<=12.761$ & LTA $>12.761$ \\
\hline \multirow[t]{2}{*}{ Brand } & -0.383 & 0.761 & 0.515 & -0.768 \\
\hline & $(1.01)$ & $(2.50)$ & $(0.88)$ & $(2.55)$ \\
\hline Premium & -0.318 & 0.878 & 0.674 & -0.536 \\
\hline $\mathrm{N}$ & 77 & 77 & 77 & 78 \\
\hline $\mathrm{F}$ & $13.19^{\mathrm{a}}$ & $16.41^{\mathrm{a}}$ & $11.71^{\mathrm{a}}$ & $16.65^{\mathrm{a}}$ \\
\hline $\operatorname{Adj} R^{2}$ & 0.88 & 0.83 & 0.74 & 0.88 \\
\hline
\end{tabular}

a significant at the $1 \%$ level. The coefficients shown in bold are significant at the $5 \%$ level or lower.

The dependent variable is the natural logarithm of audit fees.

The first row shows the parameter estimate and the second row the $t$ statistic (two-tailed) for each variable. The expected sign is positive.

Brand $=1$ if Big Firm auditor, 0 otherwise. 
Table 7 OLS Audit fee regression models of log fees against dummies for clients of audit firms that have merged over the sub-periods pre- and post each merger

\begin{tabular}{|c|c|c|c|c|c|}
\hline & & EY merger & CLD merger & PwC merger & A transaction \\
\hline Intercept & $?$ & $\begin{array}{l}\mathbf{- 1 . 3 0 1} \\
(7.70)\end{array}$ & $\begin{array}{l}\mathbf{- 1 . 5 2 9} \\
(7.87)\end{array}$ & $\begin{array}{l}-\mathbf{- 1 . 0 0 1} \\
(7.64)\end{array}$ & $\begin{array}{c}\mathbf{- 1 . 4 9 3} \\
(6.76)\end{array}$ \\
\hline LTA & + & $\begin{array}{c}\mathbf{0 . 4 6 8} \\
(33.93)\end{array}$ & $\begin{array}{c}\mathbf{0 . 4 9 8} \\
(33.48)\end{array}$ & $\begin{array}{c}\mathbf{0 . 4 4 7} \\
(39.52)\end{array}$ & $\begin{array}{c}\mathbf{0 . 5 1 2} \\
(25.40)\end{array}$ \\
\hline Sub & + & $\begin{array}{c}\mathbf{0 . 2 3 0} \\
(18.30)\end{array}$ & $\begin{array}{c}\mathbf{0 . 2 1 4} \\
(15.29)\end{array}$ & $\begin{array}{c}\mathbf{0 . 2 1 8} \\
(21.30)\end{array}$ & $\begin{array}{c}\mathbf{0 . 1 8 7} \\
(12.53)\end{array}$ \\
\hline Current & - & $\begin{array}{l}-0.043 \\
(0.93)\end{array}$ & $\begin{array}{l}-\mathbf{- 0 . 2 2 6} \\
(6.81)\end{array}$ & $\begin{array}{c}-\mathbf{- 0 . 2 2 2} \\
(8.17\end{array}$ & $\begin{array}{c}\mathbf{- 0 . 3 0 3} \\
(5.95)\end{array}$ \\
\hline Quick & + & $\begin{array}{l}0.075 \\
(1.46)\end{array}$ & $\begin{array}{l}\mathbf{0 . 2 0 6} \\
(4.78)\end{array}$ & $\begin{array}{c}\mathbf{0 . 1 8 3} \\
(5.45)\end{array}$ & $\begin{array}{l}\mathbf{0 . 3 6 3} \\
(5.12)\end{array}$ \\
\hline DTA & + & $\begin{array}{l}0.222 \\
(1.91)\end{array}$ & $\begin{array}{l}0.323 \\
(1.67)\end{array}$ & $\begin{array}{l}0.011 \\
(0.11)\end{array}$ & $\begin{array}{l}0.093 \\
(0.38)\end{array}$ \\
\hline ROI & - & $\begin{array}{c}-0.094 \\
(0.51)\end{array}$ & $\begin{array}{r}-\mathbf{0 . 6 3 4} \\
(2.53)\end{array}$ & $\begin{array}{r}-0.239 \\
(1.67)\end{array}$ & $\begin{array}{r}\mathbf{- 1 . 0 8 5} \\
(5.60)\end{array}$ \\
\hline Foreign & + & $\begin{array}{l}\mathbf{0 . 1 9 2} \\
(2.28)\end{array}$ & $\begin{array}{l}\mathbf{0 . 2 8 7} \\
(3.30)\end{array}$ & $\begin{array}{c}\mathbf{0 . 6 9 9} \\
(10.93)\end{array}$ & $\begin{array}{l}\mathbf{0 . 5 3 4} \\
(7.16)\end{array}$ \\
\hline YE & + & $\begin{array}{l}\mathbf{0 . 0 9 1} \\
(2.24)\end{array}$ & $\begin{array}{l}\mathbf{0 . 1 5 7} \\
(3.38)\end{array}$ & $\begin{array}{l}\mathbf{0 . 1 6 3} \\
(4.98)\end{array}$ & $\begin{array}{l}0.038 \\
(0.74)\end{array}$ \\
\hline Loss & + & $\begin{array}{l}0.101 \\
(1.75)\end{array}$ & $\begin{array}{l}0.107 \\
(1.65)\end{array}$ & $\begin{array}{l}0.002 \\
(0.04)\end{array}$ & $\begin{array}{l}0.108 \\
(1.62)\end{array}$ \\
\hline EYmerge & $?$ & $\begin{array}{l}-0.08 \\
(1.66)\end{array}$ & & & \\
\hline EWpre & $?$ & $\begin{array}{l}0.034 \\
(0.53)\end{array}$ & & & \\
\hline PostEY & $?$ & $\begin{array}{l}\mathbf{0 . 1 4 8} \\
(2.47)\end{array}$ & & & \\
\hline CLDmerge & $?$ & & $\begin{array}{l}\mathbf{0 . 1 3 1} \\
(2.81)\end{array}$ & & \\
\hline CLpre & $?$ & & $\begin{array}{l}0.016 \\
(0.16)\end{array}$ & & \\
\hline PostCLD & $?$ & & $\begin{array}{l}-0.003 \\
(0.04)\end{array}$ & & \\
\hline PWCmerge & $?$ & & & $\begin{array}{l}0.013 \\
(0.39)\end{array}$ & \\
\hline PWpre & $?$ & & & $\begin{array}{l}\mathbf{- 0 . 0 7 8} \\
(2.45)\end{array}$ & \\
\hline PostPWC & $?$ & & & $\begin{array}{l}-0.064 \\
(1.17)\end{array}$ & \\
\hline Dmerge & $?$ & & & & $\begin{array}{l}0.015 \\
(0.32)\end{array}$ \\
\hline DTpre & $?$ & & & & $\begin{array}{l}0.027 \\
(0.52)\end{array}$ \\
\hline PostD & $?$ & & & & $\begin{array}{l}-0.02 \\
(0.39)\end{array}$ \\
\hline $\mathrm{N}$ & & 350 & 532 & 978 & 117 \\
\hline $\mathrm{F}$ & & $304^{a}$ & $293^{a}$ & $533^{a}$ & $254^{\mathrm{a}}$ \\
\hline $\mathrm{R}^{2}$ & & 0.85 & 0.83 & 0.81 & 0.84 \\
\hline
\end{tabular}


merger): $\operatorname{LAF}_{i}=\alpha_{2,0}+\beta_{2,1}$ EWpre $_{i}+\beta_{2,2}$ PostEY $_{i}+\beta_{2,3}$ EYmerge $_{i}+\beta_{2,13}$ Controls $_{i}+\varepsilon_{2, i}$.

Model (2 CLD

merger): LAF $_{i}=\alpha_{2,0}+\beta_{2,4}$ CLpre $_{i}+\beta_{2,5}$ PostCLD $_{i}+\beta_{2,6}$ CLDmerge $_{i}+\beta_{2,13}$ Controls $_{i}+\varepsilon_{2, i}$.

Model

merger): LAF $_{i}=\alpha_{2,0}+\beta_{2,7}$ PWpre $_{i}+\beta_{2,8}$ PostPWC $_{i}+\beta_{2,9}$ PWCmerge $_{i}+\beta_{2,13}$ Controls $_{i}+\varepsilon_{2, i}$. Model $\quad(2 \quad D \quad$ takeover $\quad$ of AA): $L A F_{i}=\alpha_{2,0}+\beta_{2,10}$ DTpre $_{i}+\beta_{2,11}$ Post $_{i}+\beta_{2,12}$ Dmerge $_{i}+\beta_{2,13}$ Controls $_{i}+\varepsilon_{2, i}$.

$\mathrm{a}=$ significant at the $1 \%$ level. The coefficients shown in bold are significant at the $5 \%$ level. The first figure in each panel shows the parameter estimate and the second figure the t statistic (two-tailed) for each variable. The dependent variable is the natural logarithm of the audit fee. $\mathrm{LTA}=$ natural logarithm of total assets ( $\left.\mathfrak{£}^{\prime} \mathrm{M}\right)$; Sub = square root of the number of subsidiaries; Current $=$ ratio of current assets to current liabilities; Quick $=$ ratio of current assets less stock to current liabilities; DTA $=$ ratio of long-term debt to total assets; $\mathrm{ROI}=$ ratio of earnings before interest and tax to total assets; Foreign = proportion of subsidiaries that are foreign operations; $\mathrm{YE}=1$ if the fiscal year end is between December and March inclusive, 0 otherwise; Loss $=1$ if an operating loss was reported in any of the prior 3 years, 0 otherwise;

$E W p r e=1$ if the observation is prior to the merger and the auditor is Ernst and Whinney, if the auditor prior to the merger is Arthur Young or the observation is after the merger then EWpre is 0; PostEY $=1$ for a post-merger observation, 0 otherwise; EYmerge $=1$ for a post-merger observation where the client was originally audited by Ernst and Whinney, 0 otherwise; CLpre $=1$ if the observation is prior to the merger and the auditor at that time is Coopers and Lybrand, 0 otherwise; PostCLD $=1$ for a post-merger observation, 0 otherwise; CLDmerge $=1$ if the observation is after the merger and the original auditor was Coopers and Lybrand, 0 otherwise; PWpre $=1$ if the observation is prior to the merger and the auditor at that time is Price Waterhouse, 0 otherwise; PostPWC $=1$ for a post-merger observation, 0 otherwise; PWCmerge $=1$ if the observation is after the merger and the original auditor was Price Waterhouse, 0 otherwise; DTpre $=1$ if the observation is prior to the transaction and the auditor at that time is Deloitte Touche, 0 otherwise; $\mathrm{PostD}=1$ for a post-transaction observation, 0 otherwise; Dmerge $=1$ if the observation is after the transaction and the original auditor was Deloitte Touche, 0 otherwise. 
Table 8 OLS Audit fee regression models of log real audit fees against audit-time identity dummies for all clients over the period 1985-2002

\begin{tabular}{llcc}
\hline & & coefficient & t-statistics \\
\hline Intercept & $?$ & $\mathbf{- 1 . 2 8 6}$ & $(17.37)$ \\
EWpre & $?$ & -0.019 & $(0.23)$ \\
AYpre & $?$ & -0.038 & $(0.44)$ \\
EYpost & $?$ & $\mathbf{0 . 1 2 5}$ & $(2.06)$ \\
CLpre & $?$ & -0.099 & $(1.14)$ \\
DHSpre & $?$ & 0.039 & $(0.45)$ \\
CLpost & $?$ & $\mathbf{0 . 1 4 3}$ & $(2.74)$ \\
PWpre & $?$ & 0.057 & $(1.87)$ \\
Cpre & $?$ & 0.064 & $(1.70)$ \\
PWCpost & $?$ & 0.02 & $(0.68)$ \\
Dpre & $?$ & -0.057 & $(1.66)$ \\
Apre & $?$ & $\mathbf{- 0 . 1 0 8}$ & $(2.27)$ \\
Dpost & -0.007 & $(7.31)$ \\
NBF & $?$ & $\mathbf{- 0 . 1 6 5}$ & \\
$\mathrm{N}$ & - & 7255 & \\
$\mathrm{~F}$ & & $816^{\mathrm{a}}$ & \\
$\mathrm{R}^{2}$ & & 0.805 & \\
\hline
\end{tabular}

LRAF $_{i}=\alpha_{3,0}+\beta_{3,1}$ EWpre $_{i}+\beta_{3,2}$ AYpre $_{i}+\beta_{3,3}$ EYpost $_{i}+\beta_{3,4}$ CLpre $_{i}+\beta_{3,5}$ DHSpre $_{i}+\beta_{3,6}$ CLpost $_{i}$

Model 3: $+\beta_{3,7}$ PWpre $+\beta_{3,8}$ Cpre $_{i}+\beta_{3,9}$ PWCpost $_{i}+\beta_{3,10}$ Dpre $_{i}+\beta_{3,11}$ Apre $_{i}+\beta_{3,12}$ Dpost $_{i}+\beta_{3,13}$ NBF $_{i}$

$+\beta_{3,14}$ Controls $_{i}+\varepsilon_{3, i}$

$\mathrm{a}=$ significant at the $1 \%$ level. The coefficients shown in bold are significant at the $5 \%$ level. The first figure in each panel shows the parameter estimate and the second figure the $t$ statistic (two-tailed) for each variable. The dependent variable is the natural logarithm of the inflation adjusted (real) audit fee. EWpre takes the value of 1 if the observation is prior to the merger and Ernst and Whinney are the auditors and Ernst and Young audit the client after the merger. AYpre takes the value of 1 if the observation is prior to the merger and Arthur Young are the auditors and Ernst and Young audit the client after the merger. EYpost takes the value of 1 if the auditor prior to the merger is Ernst and Whinney and Ernst and Young audit the client after the merger. CLpre takes the value of 1 if the observation is prior to the merger and Coopers and Lybrand are the auditors and Coopers and Lybrand Deloitte audit the client after the merger. DHSpre takes the value of 1 if the observation is prior to the merger and Deloitte, Haskins and Sells are the auditors and Coopers and Lybrand Deloitte audit the client after the merger. CLpost takes the value of 1 if the auditor prior to the merger is Coopers and Lybrand and Coopers and Lybrand Deloitte audit the client after the merger. PWpre takes the value of 1 if the observation is prior to the merger and Price Waterhouse are the auditors and PricewaterhouseCoopers audit the client after the merger. Cpre takes the value of 1 if the observation is prior to the merger and Coopers and Lybrand are the auditors and PricewaterhouseCoopers audit the client after the merger. PWCpost takes the value of 1 if the auditor prior to the merger is Price Waterhouse and PricewaterhouseCoopers audit the client after the merger. Dpre takes the value of 1 if the observation is prior to the transaction and Deloitte Touche are the auditors and Deloitte audit the client after the transaction. Apre takes the value of 1 if the observation is prior to the transaction and Andersen are the auditors and Deloitte audit the client after the transaction. Dpost takes the value of 1 if the auditor prior to the transaction is Deloitte Touche and Deloitte now audits the client. $N B F$ takes the value of 1 if a non brand-name firm audits the client 